\title{
Karakteristik Gaya Tari Minangkabau Tari Mulo Pado dan Tari Benten
}

\author{
Wahida Wahyuni, Yusfil, Suharti \\ Institut Seni Indonesia Padangpanjang \\ Jalan Bahder Johan Padangpanjang 27128 \\ Email: wahidawahyuni.wewe.@gmail.com
}

\begin{abstract}
Minangkabau traditional dances have similarities in movement characters based on pencak silat as an identity attached to the Minangkabau dance. On the other hand, Minangkabau dance has different styles of embodiment between darek and pasisia. This paper builds upon an assumption that the Minangkabau dance style has special differences between darek and pasisia that is mostly influenced by their natural and cultural characteristics. By using the perspective of dance style and ethnography method, this paper aims to explain the characteristic style of Minangkabau dance by taking the examples of mulo pado dance from nagari Padang Magek (darek) and benten dance from nagari Laban Pesisir Selatan (pasisia). The results show that there is a tendency of dance embodiment between the two dances which show the differences of Minangkabau dance styles in darek and pasisia.
\end{abstract}

Keywords: dances style, body, darek, pasisia, Minangkabau

\begin{abstract}
ABSTRAK
Tari tradisional Minangkabau memiliki kesamaan karakter gerak yang berbasis pencak silat sebagai identitas yang melekat pada tari-tari Minangkabau. Namun, di sisi lain tari Minangkabau memiliki perbedaan gaya pembawaan antara darek dan pasisia. Tulisan ini dibangun berdasarkan asumsi bahwa gaya tari Minangkabau berbeda antara darek dan $p a-$ sisia yang dipengaruhi oleh alam dan corak budaya yang berbeda. Dengan menggunakan pendekatan perspektif gaya tari dan metode etnografi, tulisan ini bertujuan untuk menjelaskan gaya tari tradisional Minangkabau dengan mengambil contoh kasus tari mulo pado dari nagari Padang Magek (darek) dan tari benten dari nagari Laban Pesisir Selatan (pasisia). Hasil penelitian mengungkap kecenderungan pembawaan tari yang berbeda antara kedua tari yang menunjukkan adanya perbedaan gaya tari Minangkabau di darek dan pasisia.
\end{abstract}

Kata kunci: gaya tari, tubuh, darek, pasisia, Minangkabau 


\section{PENDAHULUAN}

Sejumlah penelitian mengenai tari tradisional Minangkabau seperti yang dilakukan oleh Utama (2017), Murgiyanto (1991) dan Sedyawati (1983), mengemukakan bahwa identitas tari Minangkabau adalah gerak yang berbasis pencak silat atau dikenal sebagai pencak. Kesamaan basis gerak tari tradisional Minangkabau dari tradisi pencak dapat dijumpai pada pelbagai tari tradisi yang berkembang di nagari-nagari Minangkabau seperti tari piring dan tari galombang. Namun demikian, belum ada penelitian yang menjelaskan bahwa tari Minangkabau memiliki karakter gerak yang berbeda antara darek dan pasisia.

Darek adalah pusat alam Minangkabau yang disebut juga dengan luhak, sedangkan pasisia adalah perluasan dari luhak yang termasuk ke dalam kawasan rantau pesisir di pantai barat Sumatera. Daerah luhak merupakan daerah asal suku bangsa Minangkabau (pusat Kerajaan Minangkabau). Secara geografis, tempat ini terletak di daerah perbukitan atau daerah ketinggian. Sedangkan pasisia adalah daerah rantau yang ada di Minangkabau yang terletak di daerah pesisir pantai bagian barat pulau Sumatera, yang dikenal dengan daerah Banda Sapuluah (Kabupaten Pesisir Selatan), Padang, Pariaman, dan Pasaman Barat sampai ke Pantai Aia Bangih (Indrayuda, 2013).

Oleh sebab itu, pembicaraan mengenai tari tradisional Minangkabau tidak dapat dilepaskan dari dua corak budaya yang berbeda tersebut. Tari-tari di kawasan darek dengan demikian dipengaruhi oleh alam dan pola kehidupan masyarakatnya yang agraris. Sebaliknya, tari-tari di pasisia, yang terletak di sepanjang pantai Barat Sumatera, memiliki kekhasan sesuai dengan alam dan masyarakat yang tinggal di daerah pantai.

Tulisan ini bertujuan untuk menjelaskan dua bentuk gaya tari tradisional Minangkabau di kawasan darek dan pasisia, yakni tari mulo pado dari nagari Padang Magek di Kabupaten Tanah Datar dan tari benten dari nagari Laban di Kabupaten Pesisir Selatan. Tari mulo pado dan tari benten adalah tarian kaba, yakni tarian yang mengangkat cerita kaba (cerita rakyat) yang disampaikan melalui tari dan nyanyian (dendang) yang memuat keluhuran nilai-nilai budaya lokal. A.A. Navis dalam bukunya Alam Terkembang Jadi Guru (1986: 272), menjelaskan karakteristik tari kaba dengan unsur utama cerita, kemudian ditarikan melalui dendang yang dinyanyikan oleh pemusik dengan menggunakan alat musik tradisional berupa saluang, talempong, atau adok. Penjelasan tersebut menunjukkan bahwa kedua tari ini memiliki gaya pembawaan yang berbeda karena latar belakang perkembangannya yang berbeda, yakni di darek dan pasisia.

Sejumlah penelitian mengenai tari Minangkabau belum ada yang menyinggung mengenai persoalan gaya tari Minangkabau darek dan pasisia. Utama (2017) dalam bukunya berjudul Tari Minangkabau, dari Pancak dan Pamenan ke Tari Persembahan membahas perkembangan tari Minangkabau dari permainan rakyat, yang dikenal sebagai pancak, ke seni pertunjukan. Utama menelusuri asal usul tari Minangkabau dari permainan rakyat yang dikenal sebagai pancak dan pamenan hingga berkembang menjadi seni pertunjukan modern. Meski tidak menyinggung tentang persoalan tari di darek dan pasisia, tulisan ini menjelaskan bahwa apa yang dinamakan dengan tari Minangkabau adalah tari-tari yang berkembang di dua kawasan tersebut. Sementara itu, Bahar, Muliati, dan Yusfil (2012), menjelaskan persoalan metode dan teknik tari Minangkabau dengan mengambil empat jenis tari, yakni: tari Adok, tari Piring Lawang, tari Luambek, dan tari Galombang. Penelitian ini mengambil sebaran tari yang ada di darek dan pasisia namun tidak ada bahasan yang menyinggung perbedaan gaya tari. Meski demikian, penelitian tersebut memberi gambaran awal mengenai gaya tari 
Minangkabau yang tengah dibicarakan. Sementara itu, tulisan tentang tari Minangkabau yang ditulis Sri Rustiyanti membahas persoalan konsep estetik tari dari tradisional ke kontemporer dengan mengadopsi konsep alua, patuik, raso pareso, untuk mengukur kompetensi penari (Rustiyanti, 2013). Tulisan ini tidak memiliki keterkaitan secara langsung namun hasil penelitiannya menjadi salah satu rujukan untuk menilai gaya pembawaan tari Minangkabau.

Persoalan gaya tari menjadi penting karena dengan mengenali gaya-gaya tari, kita bisa membedakan gaya-gaya seni tari tradisional kerakyatan (folk dances) yang berbeda dengan konteks kultural yang berbeda. Dalam interaksi sosial, tumbuh dorongan yang menyatakan eksistensi budaya, identitas diri dan budaya kolektif yang berakar dari budaya asal (Prakosa, 2009). Sejumlah referensi terkait dengan gaya tari menjelaskan bahwa gaya tari adalah sebuah penanda identitas, kespesifikan sebuah tari, atau pun sifat pembawaan tari. Royce (2007: 171) mengemukakan bahwa gaya tari adalah ciri-ciri kompleks yang menandai identitas sebuah tari. Dengan mengacu kepada tarian pada orang Meksiko, Royce menjelaskan bahwa gaya tersusun dari simbol, bentuk, dan orientasi nilai yang mendasarinya seperti pakaian, bahasa, musik, tari, tipe rumah, dan agama. Sementara itu, Allan Lomax menyatakan bahwa gaya tari adalah sesuatu yang menyebabkan tari menjadi spesifik/khas, karena sesuatu itulah bentuk tari berbeda dengan yang lain (Lomax, 1978: 222-225).

Dengan latar belakang tersebut, maka tari mulo pado dan tari benten menjadi bahasan untuk menjelaskan adanya perbedaan gaya tari Minangkabau di darek dan pasisia. Di sini, penulis sekaligus ingin menunjukkan bahwa ada keragaman gaya pembawaan dari satu genre tarian kaba dari Minangkabau.

\section{METODE}

Metode yang dilakukan penulis berangkat dari pemikiran Edi Sedyawati yang mengemukakan, bahwa gaya adalah sifat pembawaan tari, menyangkut cara-cara bergerak tertentu yang merupakan ciri pengenal dari gaya tari bersangkutan (Sedyawati, 1981: 4). Gaya tari akan dapat memunculkan sebuah bentuk tarian, seperti yang dijelaskan Sumandiyo Hadi menjelaskan bahwa bentuk adalah wujud yang diartikan sebagai hasil dari berbagai elemen tari yaitu; gerak, penari, rias, kostum, musik, properti, pola lantai dan tempat pertunjukan (Hadi, 2007: 24).

Mengacu kepada konsepsi gaya tersebut, maka metode untuk menemukan gaya tari mulo pado dan tari benten dapat dijelaskan melalui analisis terhadap aspek tekstual. Secara etnografi, aspek tekstual tersebut ditelusuri dengan melihat unsurunsur kedua tarian yang meliputi unsurunsur gerak, musik, dan elemen-elemen pendukung lainnya. Dengan melakukan upaya penelusuran identitas dan pembawaan kedua tari melalui berbagai aspek tekstual tersebut kemudian dianalisis sejumlah aspeknya, baik internal maupun eksternal yang membentuk tari tersebut hingga mendapat sebuah kesimpulan adanya gaya yang berbeda dari kedua tarian Minangkabau.

\section{HASIL DAN PEMBAHASAN}

Tari Minangkabau berdasarkan tempat pertumbuhannya terdiri atas tarian darek dan pasisia (Pesisir). Darek secara georafis terletak di dataran tinggi bukit barisan lembah gunung Merapi dan gunung Singgalang. Secara adat diistilahkan pula dengan sebutan luhak, sehingga daerah-daerah yang terdapat di daerah darek ini disebut dengan Luhak Tanah Datar, Luhak Agam, dan Luhak Lima Puluh Kota. Sedangkan pesisir menurut sejarahnya merupakan perluasan dari Luhak, sehingga dibagi pula atas tiga 
bagian yaitu Pesisir Timur, Pesisir Selatan, dan Pesisir Barat.

Secara tradisi, budaya darek dan pasisia dianggap berbeda oleh masyarakatnya, sehingga masing-masing seni pertunjukan yang hidup di kedua wilayah ini juga berbeda. Demikian pula dengan tariannya. Berdasarkan hal tersebut, ada sebagian seniman akademis di Sumatera Barat mencoba untuk mengklasifikasikan dan mengklaim bahwa tari di Minangkabau terdiri atas tarian yang bergaya darek dan tarian yang bergaya pasisia. Namun demikian, apabila merujuk pada pengertian gaya tari seperti yang dikemukan Alan Lomax bahwa gaya tari itu dapat dilihat dari wilayah pertubuhan tari, jenis tari, dan bentuk tari. Kemudian gaya ini juga dilihat dari faktor yang membangunnya, baik secara internal maupun eksternal. Sejalan dengan itu, Edi Sedyawati mengemukakan bahwa gaya tari adalah sifat atau pembawaan tari menyangkut cara bergerak tertentu yang merupakan ciri pengenal gaya tari bersangkutan (1981: 4). Dalam hubungan ini, gaya tari yang dimaksud adalah tari mulo pado yang berasal dari Luhak Tanah Datar dan tari benten yang berasal dari Pesisir Selatan itu memiliki gayanya sendiri-sendiri. Hal ini tentu akan teramati melalui aspek teknisnya, yakni melalui tubuh sebagai sebuah sistem.

\section{Gaya Tari}

Masalah gaya tari sampai saat ini masih butuh pemahaman, karena menari bukan hanya sekedar menghafal gerak. Pengertian gaya menurut kamus bahasa Indonesia adalah kekuatan atau kesanggupan untuk berbuat (KBBI: 1995, 297). Sementara pengertian gaya tari menurut Lomax (1978) adalah semua tingkah laku manusia dalam kehidupannya dikomunikasikan melalui bahasa tubuh. Bentuk-bentuk gerak yang dilahirkan sesuai dengan kebudayaannya. Dengan demikian, gaya tari merupakan kompleksitas perwujudan dari pelaku budaya sehingga faktor internal dan eksternal yang membangun gaya tari tersebut sangat menentukan kekhasan budayanya. Faktor eksternal terhadap kehadiran gaya dalam tari terungkap apabila dilakukan kajian kontekstual, sedangkan faktor internal terungkap apabila kajiannya dilakukan secara tekstual. Dari aspek tekstual ini, gaya tari muncul dari masalah-masalah teknis yang berhubungan dengan bentuk perwujudan teknik bergerak dan klasifikasi bagian tari. Dari aspek kontekstual, gaya tari terkait dengan simbol kehidupan, karena tari merupakan bagian integral sosio kultural masyarakatnya. Artinya, gaya tari akan berbeda tergantung pada pola kebudayaan pemilik tari bersangkutan.

\section{Faktor Internal yang Membangun Gaya Tari}

Tari merupakan sebuah produk yang dipahami sebagai bentuk atau struktur gerak dari penari. Tubuh bagi seorang penari/ penata tari lebih dipahami sebagai "instrumen ekspresif", sementara gerak adalah medium ekspresi. Dengan demikian, gerak tubuh penari akan menghasilkan bentuk tari, sedangkan tubuh penari akan menghasilkan gerak tari.

Pada tingkat yang paling dasar gerak muncul dalam pengertiannya sebagai "unsur" yaitu gerak-gerak yang berdiri sendiri, seperti gerak kepala, gerak lengan, tangan, gerak kaki, dan sebagainya. Akan tetapi, gerak-gerak tersebut belum memiliki makna/motivasi yang jelas sebagai gerak tari. Dalam gradasi ini, unsur gerak muncul sebagai aktifitas masing-masing bagian tubuh secara terpisah. Berdasarkan hal ini, maka tubuh adalah sebagai sistem yang memiliki subsistem-subsistem seperti dapat dilihat pada bagan 1 .

Subsistem-subsistem tubuh memiliki unsur sikap dan unsur gerak dalam sebuah tari. Hubungan unsur-unsur gerak antar subsistem pada tingkat yang paling sederhana 


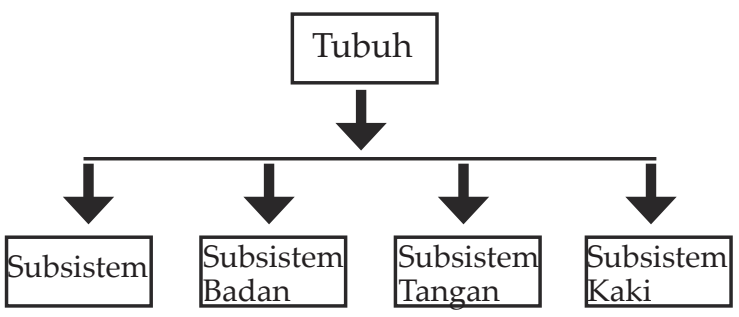

Bagan 1. Sistem dan Subsistem Tubuh

akan memberikan stimulasi terhadap lahirnya motif gerak. Dengan demikian, untuk memahami faktor internal maka perlu diketahui hal-hal sebagai berikut;

a. Sikap dasar dan dimensi tubuh. Hal ini berhubungan dengan sikap tubuh dan garis arah tubuh.

b. Peralihan dasar keseimbangan tubuh (misalnya, pitunggua tangah menjadi pitunggua belakang).

c. Sumber gerak dari tubuh atau bagian bagiannya.

d. Bentuk kaki dan pola usaha penggunaan energi dan kualitas gerak, yaitu ketepatan gerak, lembut, dan kasar. Ini berhubungan dengan pola usaha.

e. Langkah dan pola gerak.

\section{Faktor Eksternal yang Membangun Gaya Tari}

Jika faktor internal yang membangun gaya tari terkait dengan gerak, maka faktor ekternalnya, sebagai berikut.

a. Musik iringan.

b. Rias dan busana.

c. Latar belakang tari.

1) Fungsi dan maksud.

2) Arti dan/atau cerita tari.

Terkait dengan kedua faktor di atas tidak lepas dari apa yang dijelaskan Lomax bahwa gaya tari, meliputi: 1) sikap tubuh, 2) tipe transisi gerak, 3) dimensi gerak, 4) bagian tubuh yang aktif bergerak, dan 5) aksi dan usaha (Lomax, 1978: 262-273). Sejalan dengan ini, Edi Sedyawati juga mengemukakan bahwa gaya tari adalah sifat pembawaan tari, menyangkut cara-cara bergerak tertentu yang merupakan ciri pengenal dari gaya tari bersangkutan (Sedyawati, 1981: 4). Untuk memahami gaya tari yang diuraikan Lomax, dapat dijelaskan bahwa: 1) sikap tubuh yang terdiri dari kepala, badan, tangan, dan kaki menunjukkan sikap dasar berdiri di mana segala aktivitas dan langkah dikembangkan. 2) Tipe transisi terjadi apabila gerak berubah arah. Sifat dasar transisi adalah menyambung gerak awal dan lanjutan. 3) Sedangkan dimensi gerak dalam tari ada tiga, yaitu a) bentuk gerak yang sederhana, hanya dapat dilihat dari satu arah atau dari depan saja, b) variasi gerak, tubuh penari dapat dilihat dari dua arah, depan dan samping badan, c) gerak yang mengolah ruang secara variatif, misalnya berputar dan lain sebagainya dapat dilihat dari berbagai arah, 4) bagian tubuh yang aktif merupakan banyak atau sedikitnya jumlah bagian anggota tubuh yang bergerak sebagai instrumen ekspresi, 5) aksi dan usaha, aksi adalah wujud gerak yang dilakukan penari dengan ruang sekitarnya. Sedangkan usaha adalah cara berpindah untuk menghasilkan kualitas gerak yang kemudian memberi makna pada tari.

\section{Gaya Tari Mulo Pado}

Tari mulo pado merupakan tari tradisional yang berkembang di daerah Padang Magek, Kabupaten Tanah Datar. Tari ini dahulunya bernama tari lamo, yaitu tari yang telah lama hadir di tengah masyarakat. Tari lamo pada awalnya merupakan tarian pembuka sandiwara Cindua Mato di nagari Padang Magek pada tahun 1980-an (wawancara dengan Syafwardi, Mei 2017). Tarmizi, seorang seniman tradisi sekaligus pelaku tari mulo pado kemudian berinisiatif menjadikan tari lamo berdiri sendiri dan terpisah dari sandiwara Cindua Mato. Hal ini dilakukannya sebagai upaya pelestarian agar penyajian tari mulo pado tidak terlalu lama sehingga dapat berkembang di tengah masyarakat pemiliknya. Dari pene- 
lusuran kepustakaan diketahui bahwa Chairul Harun (alm), seorang budayawan Minangkabau dan juga ketua Badan Koordinasi Nasional Indonesia (BKKNI) Tingkat ISumatera Barat, mengubah nama tari lamo menjadi tari mulo pado karena kebutuhan Pekan Tari Rakyat yang diadakan di Batusangkar Sumatera Barat yang berlangsung tanggal 14-17 Oktober 1979 (Daryusti, 1992: 11). Hal ini diterima masyarakat setempat sehingga sampai saat ini tari lamo dikenal sebagai tari mulo pado.

Tari mulo pado pada mulanya berfungsi sebagai bagian dari upacara adat dan acara alek nagari di nagari Padang Magek. Namun, saat ini tari mulo pado juga ditampilkan di berbagai acara hiburan lainnya. Secara tekstual, tari ini telah mengalami banyak perubahan karena keterbatasan Syamsir (80 tahun) sebagai pewaris langsung tari mulo pado yang mengajarkan tari tersebut sebatas apa yang masih mampu ia ingat. Di sisi lain, seniman lainnya juga mengembangkan gaya mereka sendiri-sendiri. Hal ini menyulitkan peneliti untuk menelusuri bentuk asli tari mulo pado secara utuh, termasuk nilai dan makna filosofisnya. Tari mulo pado atau jika diartikan dalam bahasa Indonesia berarti awal mula, mengisahkan tentang tiga tokoh adat legendaris Minangkabau yang dikenal dengan niniak mamak nan batigo, yaitu Datuk Maharaja Nan Banego-nego, Datuk Katumanggungan, dan Datuk Perpatih nan Sabatang. Ketiga datuk ini merintis wilayah tempat pemukimannya dari puncak gunung merapi melalui tiga daerah, yaitu daerah Kumango, Lintau, dan Pariangan. Pemukiman yang dibangun tersebut kemudian diberi nama Padang Magek (Anwar, wawancara, 3 Agustus 2017 di Padang Magek). Kisah asal muasal terjadinya pemukiman inilah yang kemudian ditarikan ke dalam tari mulo pado.

Tari mulo pado pada mulanya ditarikan oleh dua orang pria, namun dalam perkembangannya tari ini ditarikan se- cara berpasangan oleh perempuan. Penari mulo pado memakai kostum yang disesuaikan dengan syariat Islam dan kostum adat Minangkabau dengan warna-warna marawa dari tiga luhak, yaitu merah, hitam, dan kuning. Penari pria menggunakan pakaian silat yang terdiri dari baju gadang, sarsawa galembong dan destar. Sedangkan penari perempuan memakai kostum adat Padang Magek. Struktur penyajian tari mulo pado ini dapat dibagi menjadi tiga bagian, yaitu bagian awal sebagai pembuka tarian terdiri dari gerak sambah dan gerak cabiak. Bagian tengah merupakan gerak pokok terdiri dari gerak Parampek Bumi, Barabah tabang duo, Adau-adau, Rantak limo dan Siamamng Tagagau. Bagian tengah ini merupakan penggambaran tentang isi dan makna tari dari gerak-gerak yang dihasilkan. Setiap peralihan dari gerak pokok selalu diselingi oleh gerak pasisik yang menjadi gerak transisi pada tari mulo pado. Bagian akhir adalah bagian penutup dari tari mulo pado yang terdiri dari gerak kain dan gerak padang.

Berdasarkan hal di atas, tari mulo pado memiliki urutan gerak sesuai dengan kisah perjalanan Niniak mamak nan batigo, yaitu (1) Sambah, (2) Cabiak, (3) Parampek Bumi, (4) Barabah tabang duo, (5) Adau-adau, (6) Rantak limo, (7) Siamang tagagau, (8) Kain, dan (9) Padang. Namun gerak kain dan gerak pedang tidak lagi dijumpai pada tari mulo pado yang berkembang saat ini. Urutan gerak tari mulo pado dapat dijelaskan sebagai berikut.

1) Gerak sambah (sembah) yang dimaknai sebagai penghormatan kepada Sang Pencipta langit dan bumi. Gerak sambah dilakukan dengan manakuan kapalo nan satu, maangkek jari nan sapuluah (menekurkan kepala yang satu, mengangkat jari yang sepuluh) yang berarti menundukkan kepala sambil mengangkat kesepuluh jari sebagai tanda sujud kepada Sang Pencipta. Gerak diawali dengan menggerakkan kedua lengan ke arah samping kanan badan, lalu 
digerakkan ke arah depan badan. Seiring dengan itu, kedua kaki dibuka dengan posisi pitunggue belakang, yaitu kaki kanan diseret ke belakang bersamaan dengan kedua pergelangan tangan galatiak (aksentuasi pada pergelangan tangan) di depan badan yang digerakkan kearah paha kiri. Lalu, badan diputar setengah lingkaran (pilin) kemudian melangkah kearah pasangan seiring dengan kedua tangan melalui kedua sisi badan yang digerakkan dari bawah keatas. Kedua ujung jari tangan menyentuh lantai sebagai tanda memberi penghormatan kepada bumi dan langit dalam posisi duduk yang bertumpu pada tungkai kanan.

2) Gerak cabiak yang menggambarkan usaha merintis jalan ketika merambah hutan agar perjalanan untuk mencari pemukiman berjalan lancar. Kekhasan gerak cabiak terletak pada gerak tangan yang selalu berlawanan, satu mengarah ke atas dan satunya lagi ke arah bawah, seperti gerakan tengah mencabik (merobek) atau membelah sesuatu. Gerak ini dilakukan dengan menggerakkan tangan kanan di depan badan seiring dengan memberi aksentuasi pada pergelangan tangan kanan, posisi kaki pitunggue tengah, serta tangan kiri ditempelkan pada pinggang. Gerak ini dilakukan berbalasan sesuai dengan posisi arah hadap penari.

3) Gerak parampek bumi yang dimaknai sebagai upaya untuk mencari sumber kehidupan. Gerak parampek bumi dicirikan dengan gerakan kaki yang menghentak ke empat arah hadap. Gerak ini diawali dengan melangkahkan kaki kanan dan kaki kiri secara bergantian ke arah pasangan. Seiring dengan itu kedua telapak tangan dipertemukan di depan badan dengan posisi telapak tangan kiri di bawah. Ketika kaki kanan dilangkahkan bergantian dengan kaki kiri, maka kedua posisi telapak tangan dipertemukan berlawanan dengan posisi kaki yang jadi penutup dari gerak. Gerak ini selalu dilakukan berbalasan antara kiri dengan kanan.

4) Gerak barabah tabang duo yang menggambarkan kegembiraan Niniak mamak nan batigo ketika mendapatkan pemukiman. Gerak ini memiliki kekhasan pada gerak tangan yang selalu beriringan, menirukan gerak terbang burung barabah yang terbang seiring. Gerakan dimulai dengan melangkahkan kaki kanan dan kaki kiri bergantian ke arah pasangan. Kemudian kedua penari dengan posisi pitunggue kanan, membuka kedua tangan ke arah samping kiri dan kanan dengan posisi ujung jari keatas. Selanjutnya, gerakan dilakukan secara bergantian dengan cara melakukan balasan dari gerakan sebelumnya.

5) Gerak adau-adau dimaknai sebagai rintangan atau halangan selama melakukan perjalanan. Sesuai dengan nama geraknya adau-adau (aduh-aduh), gerakan ini lahir dari keterkejutan karena adanya rintangan yang menghalangi. Ciri khas gerak ini terletak pada gerak kaki yang mencacah dan kemudian diangkat tiba-tiba, seperti reflek seseorang yang terkejut karena sesuatu menghalangi langkah kakinya. Gerak adauadau diawali dengan merentakkan kaki kanan masing masing pasangan kemudian kaki kanan tersebut menyilang kaki kiri dengan posisi jongkok. Kedua tangan dibawa lurus ke depan badan dengan posisi kedua ujung jari ke atas.

6) Gerak rantak limo yaitu gerakan hentakan kaki yang dilakukan ke lima arah. Pemaknaan dari gerak rantak limo ini adalah tentang perselisihan Niniak mamak nan batigo. Gerak ini diawali dengan merentakkan kaki kanan kearah depan (pasangan) kemudian dilanjutkan ke depan, ke samping kiri, ke kanan, dan ke belakang (empat arah). Seiring dengan itu, tangan kiri melakukan gerak pancuang kiri dengan memberikan aksentuasi pada pergelangan tangan. Begitu juga sebaliknya gerakan ini dilakukan berbalasan antara kiri dan kanan. 
7) Gerak siamang tagagau yang dimaknai sebagai keterkejutan Niniak mamak nan batigo ketika melihat seekor binatang menghalangi perjalanan mereka di hutan belantara. Gerak ini ditandai dengan gerakan hentakan kaki yang tiba-tiba sebagai ungkapan keterkejutan seperti halnya siamang tagagau. Dalam bentuk geraknya, kaki kanan direntakkan ke arah serong kanan dan tiba-tiba berhenti, kemudian menyilang dengan kaki kiri dengan posisi jongkok kearah yang sama. Kedua tangan dibuka lurus membuat sudut 650 dengan posisi ujung jari keatas. Kemudian dengan bentuk gerak yang sama dilakukan kebalikannya, yaitu kaki melangkah serong kanan belakang dan berhenti.

8) Gerak kain dimaknai sebagai ungkapan perselisihan pendapat atau kehatihatian Niniak mamak nan batigo ketika merambah lahan. Gerak ini ditandai dengan pemakaian properti berupa kain sarung atau kain panjang yang dipakai untuk menari. Gerak ini diawali dengan melangkahkan kaki kanan dan kiri kearah pasangan seiring dengan memutar badan (pilin) ke arah yang sama. Seiring dengan itu, kedua tangan mendorong lurus kearah pasangan dengan posisi kedua tangan memegang kain. Kedua penari melakukan gerakan berlawanan antara kiri dan kanan sesuai dengan langkah dari penari yang menjadi patokan untuk perpindahan tempat.

9) Gerak padang adalah gerakan memakai properti pedang yang distrukturkan sebagai penutup dari tari mulo pado. Gerakan padang ini lebih banyak berupa gerak pencak silat yang dimaknai sebagai ketangkasan, kewaspadaan, dan kebijakan dari Niniak mamak nan batigo atas keberhasilannya mendapatkan lahan sesuai dengan apa yang diharapkan. Gerak padang ditandai dengan sejumlah gerakan, yakni langkah tigo, langkah limo, pancuang, tusuak, balabeh, timpo, dan sepai. Gerakan padang ini bersifat spontanitas. Sikap tubuh dalam penya-

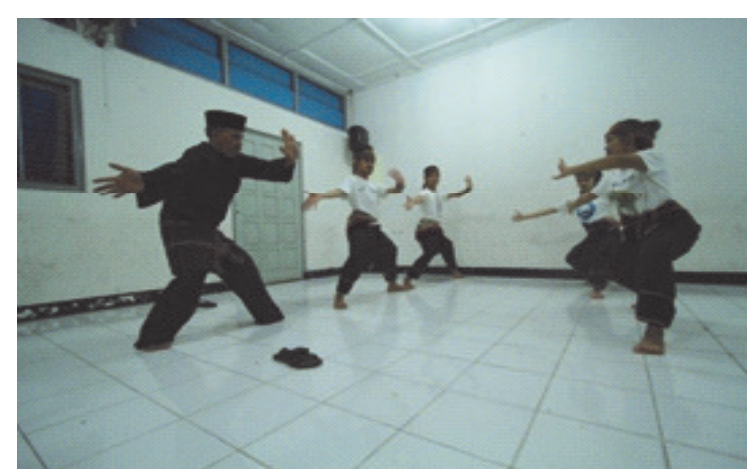

Gambar 1. Gaya pembawaan tari mulo pado (Dokumentasi Tim Peneliti dalam rekonstruksi gerak tari mulo pado di kampus ISI Padangpanjang, 10 Juli 2017)

jian tari Mulo Pado dapat dilihat pada gambar 1 .

Sementara itu, ditinjau dari aspek musik, tari mulo pado pada awalnya diiringi dengan dendang dan permainan saluang. Namun dalam perkembangannya, tari ini hanya diiringi dengan permainan saluang, dan diperkaya dengan beberapa instrumen pengiring lainnya, yaitu gandang katindik dan talempong pacik yang mendukung menciptakan suasana yang gembira dan bersemangat sesuai dengan kisah tari mulo pado yang menggambarkan aktivitas Niniak mamak nan batigo dalam membuka lahan baru sebagai pemukiman. Dalam konteks tulisan ini, musik iringan tari mulo pado adalah permainan saluang dengan judul Singkarak lamo.

Secara keseluruhan, gaya pembawaan tari mulo pado erat kaitannya dengan latar belakang kehidupan masyarakat Padang Magek yang umumnya bertani. Sementara gerak tari mulo pado sendiri adalah turunan dari gerak silek tuo, yaitu silat yang berkembang di kawasan luhak dengan ciri khas gerakan pada posisi pitunggue (kudakuda) yang kokoh, kemampuan mengelak (gelek) yang cepat, serta berbagai variasi gerakan lengan di depan badan untuk melindungi bagian-bagian badan yang vital (Utama, 2017: 46). Pengaruh silek tuo dapat dilihat pada unsur sikap tubuh terdiri dari kepala yang selalu tegak, badan tegak, ta- 


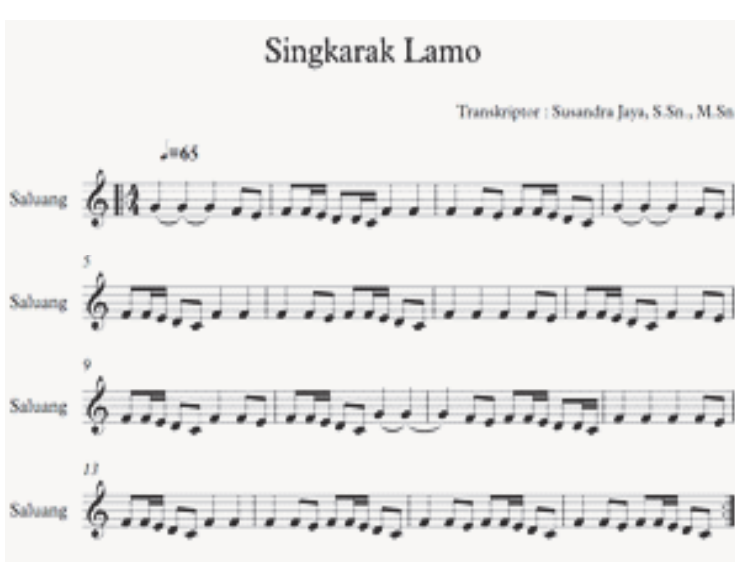

Gambar 2. Notasi Lagu Singkarak Lamo

ngan membuka membentuk tagak jari ampek, dan kaki berdiri kokoh dalam posisi pitunggue. Sedangkan unsur gerak pada sub-sub sistem terdiri dari: kepala yang mengikuti gerak lengan, badan pilin suok (kanan) dan pilin kida (kiri), tangan galatiak, serta kaki rantak dan tagak itiak. Tari mulo pado memiliki tipe gerak transisi yang mempunyai motif tersendiri yang dinamai dengan pasisik. Gerak pasisik selalu diawali dengan sikap lengan dalam bentuk timpo dan kaki dengan posisi silang melangkah kearah pasangan untuk merubah arah hadap ke depan, ke belakang, dan ke samping, untuk melanjutkan gerak bagian per bagian. Oleh karena itu, tipe transisi pada tari mulo pado adalah setiap peralihan bagian tari dihubungkan oleh gerak pasisik.

Dengan demikian, gaya pembawaan tari mulo pado ditandai dengan sikap kaki yang selalu kokoh dan membuka lebar (pitunggue), begitu pula dengan posisi tangan yang selalu membuka. Gerak tari mulo pado didominasi oleh gerakan pada kedua lengan karena makna setiap gerakan terdapat pada gerakan lengan yang menggambarkan kisah yang diceritakan. Dari aspek ruang gerak, hampir semua gerakan dilakukan dengan ruang gerak yang membuka lebar seperti halnya gerakan dalam silek tuo yang cenderung bertahan dalam pitunggue yang kokoh sebagai ungkapan kewaspadaan.

\section{Gaya Tari Benten}

Tari benten adalah tari yang berkembang di Nagari Laban Kecamatan IV Jurai Kabupaten Pesisir Selatan. Ada dua versi yang menjelaskan tentang kehadiran tari benten. Versi pertama mengemukakan bahwa tari benten mengisahkan tentang kehidupan sebuah keluarga, yaitu seorang ibu yang bijaksana bernama Benten, dan ayah bernama Adau Adau. Keluarga ini memiliki dua orang anak bernama Buai Buai dan Rantak Kudo (Herawati, 2006: 1). Kedua, tari benten merupakan penggambaran dari alam yaitu burung elang. Gerakgerak tari benten menggambarkan seekor burung elang yang tengah terbang di siang hari (Hartati, 1992: 25). Tulisan ini mengacu kepada versi pertama yang dianggap sesuai dengan keterangan narasumber di lapangan dan merupakan versi yang umum dijumpai.

Sebagaimana halnya tari mulo pado, tari benten memiliki gaya tersendiri yang secara koreografis juga dapat dianalisis terkait dengan elemen-elemen yang distrukturkan oleh seniman penciptanya. Bila dilihat dari informasi nara sumber tentang pendapat yang pertama, mengatakan bahwa tari ini menceritakan tentang kehidupan keluarga, maka struktur tarian pada bahagian awal di mulai dengan gerak pokok padendangan yang berisikan tentang syair menidurkan anak. Kemudian gerak kasang, gerak panjang, gerak sibadindin, gerak adau-adau dan gerak rantak kudo menceritakan tentang aktifitas sehari-hari dalam keluarga, yang diperkuat oleh syair dendang pemusik. Sementara itu, untuk informasi kedua mengatakan bahwa tari bnten merupakan peniruan dari pada gerak burung elang yang sedang terbang berputar-putar (bentan-bentan) di siang hari. Pendapat yang kedua ini bila dikaitkan dengan struktur dan bentuk gerak tari dari awal, tengah, dan akhir secara keseluruhan tidak menggambarkan aktivitas ataupun pemaknaan 
tentang keperkasaan burung ini. Dengan demikian, pada tari benten pola-pola gerak dasar dalam tarian sangat erat kaitannya dengan informasi pertama. Hal ini juga diperkuat dengan syair yang didendangkan oleh pemusik yang menceritakan tentang kehidupan dalam suatu keluarga.

Tari benten pada awalnya ditarikan oleh dua orang penari pria, namun saat ini tari benten juga ditarikan oleh perempuan secara berpasangan dalam jumlah genap. Struktur tari benten mengikuti cerita yang mengisahkan kehidupan dalam suatu keluarga, yang terdiri dari gerak pokok padendangan yang berisikan tentang syair menidurkan anak. Kemudian gerak kasang, panjang, sibadindin, adau-adau, dan rantak kudo, menceritakan tentang aktivitas seharihari dalam keluarga, yang diperkuat oleh dendang dan diiringi alat musik adok.

Secara tekstual, tari benten mengalami perubahan seperti tari mulo pado. Hal ini disebabkan karena pewarisan yang tidak berjalan dengan baik dimana seniman tari benten menumbuhkembangkan tari ini sebatas melatihkan gerak-gerak tarian kepada generasi muda sehingga cenderung menghilangkan nilai dan makna filosofisnya.

Sebagaimana narasi yang disampaikan melalui dendang atau nyanyian yang dibawakan oleh pemusik berupa syair yang didendangkan, maka urutan gerak yang terdapat pada tari benten adalah 1) padendangan, 2) kasang, 3) panjang, 4) adau-adau, 5) sibadindin, dan 6) rantak kudo.

1) Gerak padendangan, menggambarkan kelemah-lembutan dan kesabaran seorang ibu dalam mendendangkan anaknya yang ditandai dengan gerakan tangan yang membuka dan diayun ke depan secara berlawanan antara tangan kanan dan kiri dengan ujung jari tengah digerak-gerakkan (garitiak) diiringi dendang yang berirama magis. Sikap awal ditandai dengan posisi penari tegak lurus, kemudian kaki kanan dilangkahkan lebar ke belakang membuat pitunggua suok (kanan). Sejalan dengan itu, kedua tangan diayunkan lurus ke depan dada, kemudian kedua jari jari tangan (jari tengah dan ibu jari) digerakkan 4 hitungan. Gerak ini ditutup dengan menyeret kaki kanan kearah kaki kiri seiring dengan posisi tangan kanan menyiku di depan dada dan tangan kiri lurus sejajar badan dengan posisi ujung jari tangan ke bawah. Gerak padendangan diiringi oleh dendang padendangan yang dinyanyikan dengan tempo musik sedang yang terdiri dari satu bait pantun kemudian diberi kata-kata tambahan intro serta penutup. Baris kata-kata inilah yang didendangkan menjadi sebuah melodi. Melodi ini diikat oleh bunyi adok sebagai pengatur ritme melodi.

2) Gerak kasang yang mengisahkan penghormatan terhadap seorang ibu. Gerak ini dicirikan dengan kepala yang agak menunduk dengan kaki kiri dan kanan bersilangan, serta kedua tangan melenggang. Gerak ini diiringi oleh dendang kasang yang didendangkan dengan tempo musik sama namun dengan teks pantun yang berbeda. Bunyi adok selalu bersamaan dengan melodi dendang. Gerak ini diawali dengan melangkahkan kaki kanan ke arah samping kanan dengan posisi pitunggue kanan, kaki kiri ditekuk, serta kedua tangan digerakkan dari samping kiri ke arah kanan dengan posisi akhir kedua tangan melengkung di depan badan dengan ujung jarikiri ke bawah dan ujung jari kanan ke atas. Kemudian kaki kanan melangkah ke arah pasangan sebanyak dua hitungan, diikuti oleh kaki kiri, lalu mundur dua hitungan ke posisi semula. Seiring dengan itu, kedua tangan melakukan gerak lenggang, yang dimaknai sebagai sikap siaga untuk menyerang atau menangkis. Hal ini merupakan makna tersirat bahwa bila ada bahaya, rintangan dapat diatasi atau diselesaikan.

3). Gerak panjang yang mengisahkan lika-liku kehidupan berumah tangga. Gerak ini berpusat pada kaki dimana kaki kanan 
atau kaki kiri dari masing masing penari diangkat, lalu dilangkahkan serong kanan dengan posisi kaki pitunggue, kaki kiri lurus dibelakang. Kedua tangan suduang daun di atas kepala. Gerak ini dilakukan delapan hitungan kiri dan kanan dilakukan secara bergantian. Gerak panjang dimaknai sebagai ketabahan dan keuletan. Gerak panjang diiringi oleh dendang panjang dimana musik diawali dengan tempo agak cepat dengan dinamika yang keras. Bunyi adok selalu pada melodi ritme terikat.

4) Gerak adau-adau, mengisahkan tentang parasaan atau suka duka hidup. Gerak ini dicirikan dengan ruang gerak sempit/ menutup dimana kedua tangan didorong ke depan dibawa menyilang di depan dada dengan posisi timpo (tangan kanan menghimpit tangan kiri dalam posisi menyilang) diiringi dendang adau-adau. Dendang adau-adau dimainkan dengan tempo musik sedang, serta melodi keseluruhan menggunakan ritme terikat dengan bunyi adok yang samadari awal sampai akhir. Gerakan dimulai dengan kaki kanan dilangkahkan ke arah lawan, kemudian menyilang dengan kaki kiri sehingga membentuk posisi pitunggue. Tangan kiri dan kanan diayun dari bawah keatas dengan posisi kedua siku ditekuk. Pada hitungan keempat, posisi badan rendah dan kaki menyilang. Kemudian kedua penari berputar yang disebut dengan babaleh, yang diikuti dengan buka kaki kanan satu langkah (langkah satu), oleh senimannya merupakan langkah alif yang dimaknai sebagai manusia mengharapkan Ridhonya Allah.

5) Gerak sibadindin yang menggambarkan suasana gembira dimana segala persoalan yang dihadapi dapat diselesaikan dengan baik. Gerak sibadindin dicirikan oleh gerak kaki yang batingkah/rantak cupu dimana kaki bergerak dengan langkah-langkah pendek diiringi dendang sibadindin yang bernada gembira. Dendang sibadindin dinyanyikan dengan tempo musik agak cepat dari sebelumnya. Gerak ini dilakukan dengan kaki kanan diangkat, lalu diturunkan membentuk sudut 1800, serta posisi kaki kiri menapak dengan ujung jari berada di samping kiri. Tumit dan ujung jari kemudian digerakkan secara bergantian sebanyak empat hitungan. Sementara itu, lengan kiri menyiku membentuk sudut 900 di depan dada, dengan ujung jari tangan tegak lurus. Tangan kanan lurus di samping badan dengan telapak tangan arah atas, serta posisi badan arah ke samping.

6). Gerak rantak kudo adalah urutan gerak terakhir pada tari benten yang menggambarkan kegembiraan atau kebahagiaan sebuah perjalanan hidup. Gerak rantak kudo dicirikan oleh langkah kaki yang merentak ringan, cepat, dan pendek-pendek seperti halnya kaki kuda yang merentak, diiringi dendang rantak kudo bertempo cepat dan jumlah pantun tidak terikat karena ditentukan oleh kehendak gerakan tari yang sifatnya gembira. Gerak rantak kudo diawali dengan gerakan membuka kaki kanan atau kaki kiri sesuai dengan posisi penari, kemudian kaki yang di belakang ditekuk sementara ujung jari kaki yang berada di depan diangkat dengan posisi tumit berada di lantai. Kemudian ujung jari kaki dihentakkan ke lantai secara bergantian dengan tumit sebanyak empat hitungan. Kedua tangan secara bergantian melakukan gerak ayun di depan badan seiring dengan kepala dianggukkan ke bawah dan ke atas.

Sementara itu, musik menjadi bagian yang sangat penting dalam tari benten, hal mana masing-masing cerita disampaikan melalui dendang yang berbeda-beda sesuai dengan nama gerak yang sedang diragakan, seperti yang diuraikan sebelumnya. Musik tari benten juga memiliki kekhasan pada penggunaan alat musik pukul yang disebut adok yang dimainkan oleh dua orang untuk menciptakan suasana yang berkesan magis. Adok adalah alat perkusi bermuka satu, menghasilkan bu- 


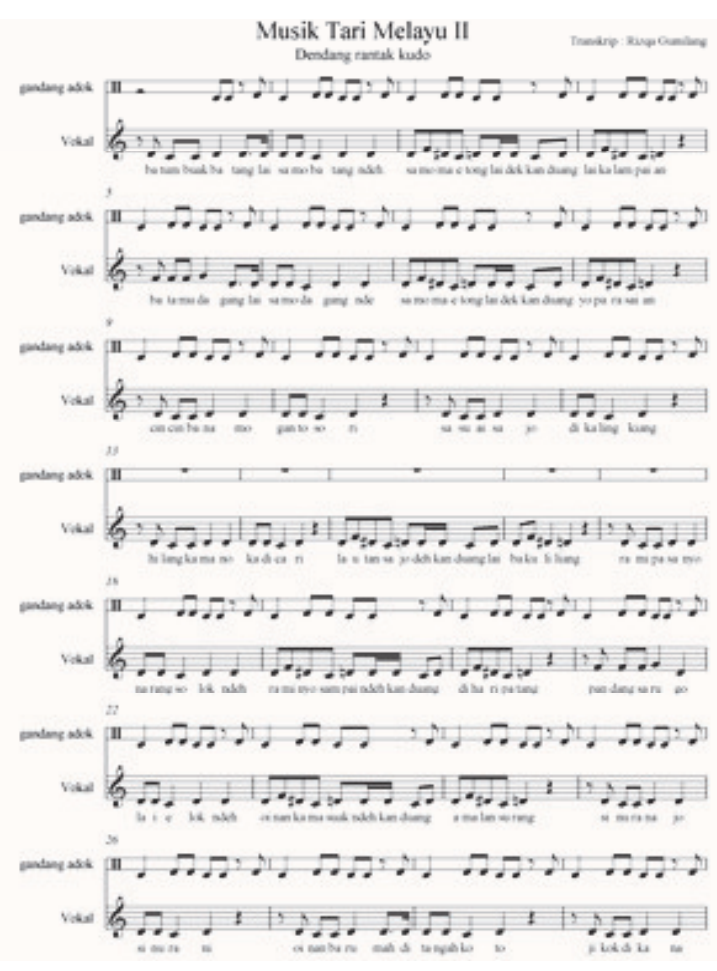

Gambar 3. Notasi Musik Tari Benten

nyi yang dimainkan secara duduk bersila dengan cara meletakkan adok di atas kaki, sedangkan permukaannya menghadap ke depan yang dipegang oleh kedua tangan. Bagian belakang adok yang terbuka berfungsi sebagai rongga resonansi. Alat musik ini dimainkan dengan cara ditabuh dengan telapak dan jari tangan. Dendang berperan untuk menyampaikan ungkapan-ungkapan teks yang berisi pantun. Pantun yang didendangkan tidak utuh sebagai sebuah pantun, melainkan pantun yang dipenggalpenggal oleh kata-kata tambahan sebagai pembawaan melodi. Sedangkan alat musik adok berperan sebagai pembawa ritme yang variatif dalam sebuah komposisi musik tari benten. Jumlah pemain musik untuk mengiring tari benten minimal dua orang, satu orang berperan memainkan adok untuk menghasilkan ritme sekaligus sebagai pendendang, dan seorang lagi khusus sebagai pendendang untuk menyuarakan teks-teks pantun dengan kata-kata tambahan. Struktur musik tari benten dapat dikatakan sudah baku yang mengandung cerita sesuai pula dengan struktur dan bentuk tarian-

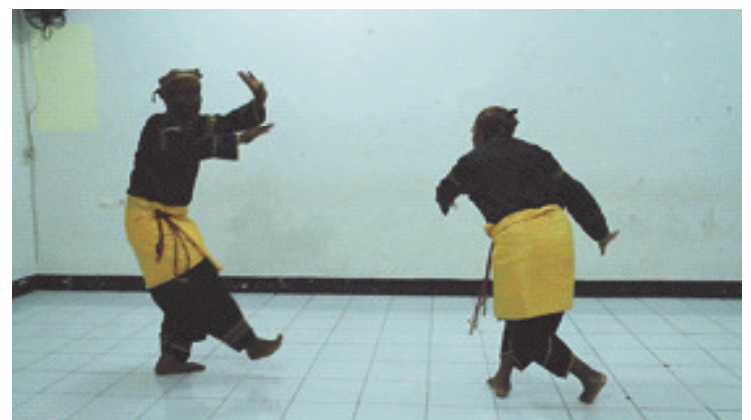

Gambar 4. Gaya pembawaan tari benten (Dokumentasi tim peneliti di ISI Padangpanjang, 10 Juli 2017)

nya. Adapun salah satu notasi musiknya dapat dilihat pada ilustrasi 3.

Gaya pembawaan tari benten sangat dipengaruhi oleh pengaruh konteks alam pasisia yang berbeda dari darek. Menurut cerita seniman setempat, tari ini pada awalnya berasal dari darek dengan gerak yang didasari oleh silek kumango. Meski demikian, gerakan tersebut dibawakan dengan cara berbeda ketika sampai di kawasan pesisir yang dipengaruhi oleh silek luncua yang berkembang di pesisir dengan karakter gerak yang terkesan meluncur. Tari benten memiliki kekhasan gerak yang terletak pada gerakan kaki yang variatif dengan langkah-langkah yang pendek dan ringan. Dominannya gerak kaki ditandai dengan nama-nama gerak seperti gerak basitinjek, antak tumik, pijak baro, dan rantak cupu. Sementara itu, gerak tangan selalu mengayun atau melenggang mengikuti gerak kaki, dengan ciri khas gerak kaluak paku dengan menggunakan gonyek bahu.

Adapun sikap tubuh pada tari benten dicirikan dengan kepala tagak dan takua dengan badan condong ke depan seperti orang tengah menarik pukat. Kaki dalam posisi pitunggua dan tangan dalam posisi bukak, namun dengan ruang yang lebih sempit. Unsur gerak kepala berupa angguak, badan galeong, tangan pauh dilayang dan garitiak, serta kaki lapiak ujuang jari. Dalam tari benten pada setiap perpindahan gerak, penari akan mengikuti pola ritme dari iringannya. Transisi selalu diawali dengan 
pilin suok, kemudian penari merubah arah hadap ke depan dan ke belakang untuk melanjutkan gerak berikutnya.

Dengan demikian, gaya pembawaan tari benten lebih bersifat dinamis, ditandai dengan gerakan kaki lebih dinamis, gerakan tangan cenderung mengayun.

\section{SIMPULAN}

Gaya tari Minangkabau yang berbeda antara darek dan pasisia merupakan hal yang jarang diungkap dalam sejumlah referensi penelitian mengenai tari Minangkabau yang lebih banyak membahas mengenai identitas gerak yang berbasis pencak silat. Ada perbedaan dalam gaya pembawaan tari di darek dan pasisia, seperti pada tari mulo pado dan tari benten yang merupakan tarian kaba yang bersifat naratif dengan pola pembabakan tarian yang hampir sama. Gaya pembawaan tari mulo pado dipengaruhi oleh silek tuo yang memiliki kekhasan pada sikap tubuh yang selalu tagak (tegak) dengan pitunggue (kuda-kuda) yang kokoh. Posisi kaki dan tangan selalu membuka dengan ruang gerak yang lebar. Gerakan secara umum didominasi oleh gerak tangan yang cenderung beriringan. Semua ciri gerak tersebut merupakan gambaran alam dan kehidupan masyarakat darek yang agraris. Sebaliknya, gaya pembawaan tari benten ditandai dengan sikap tubuh condong ke depan dengan gerakan yang dominan terletak di kaki. Gerakan kaki cenderung ringan, pendek-pendek dan variatif, sesuai dengan nama-nama gerak yang ada, yakni basitinjek, pijak baro, rantak cupu, dan rantak kudo. Sementara itu, tangan cenderung mengayun mengikuti gerak kaki dengan arah hadap yang selalu berlawanan. Oleh karena itu, ruang gerak kaki dan tangan cenderung sempit. Gaya pembawaan tari benten memiliki keterkaitan dengan konteks alam dan budaya pesisir.

Perbedaan gaya pembawaan tari mulo pado dan tari benten yang terungkap me- lalui analisis bentuk dan karakter gerak, membuktikan asumsi adanya perbedaan gaya tari Minangkabau antara darek (tari mulo pado) dan pasisia (tari benten). Pada prinsipnya, tari tradisional Minangkabau tidak memiliki standar gerak yang baku yang menjadi acuan secara umum, namun hasil penelitian ini menjelaskan adanya kecenderungan gaya yang berbeda yang dilatarbelakangi oleh perbedaan konteks perkembangan tari di darek dan pasisia.

Dengan demikian, simpulan kajian ini dapat memberikan kontribusi kepada masyarakat pemilik, terutama pada tari mulo pado yang hampir punah saat ini, sehingga tari ini didokumentasikan kembali sesuai dengan data-data yang diperoleh dari hasil tinjauan pustaka yang dilakukan peneliti sebelumnya, dan dari berbagai sumber di lapangan. Untuk tari benten, atas kerjasama dengan Dinas Pendidikan dan Kebudayaan Pesisir Selatan, dilakukan dokumentasi ulang untuk merumuskan karakteristik tari sebagai pembeda dengan tari mulo pado dari daerah darek. Berdasarkan hal ini karakterisitik tari dapat ditularkan dari generasi ke generasi.

\section{Daftar Pustaka}

Bahar, M., Muliati, R., Yusfil. (2012). Metode dan Teknik Tari Minangkabau sebagai Dasar Pengembangan Tari Kreasi. PePenelitian Unggulan Perguruan Tinggi Institut Seni Indonesia Padangpanjang. ISI Padangpanjang, Padang Panjang Sumatera Barat.

Daryusti, dkk. (1992). Tari Mulo pado di Kenagarian Padang Magek Kecamatan Rambatan. Akademi Seni Karawitan Indonesia, Padang Panjang Sumatera Barat.

Hadi, Y. S. (2007). Kajian Tari Teks dan Konteks. Yogyakarta: Pustaka Buku Publisher. Hartati. (1994). Tari Benten di Desa Laban Kecamatan IV Jurai Kabupaten Pesisir Selatan. (Laporan penelitian). Akade- 
mi Seni Karawitan Indonesia (ASKI) Padangpanjang.

Herawati. (2006). Teknik Permainan Musik Tari Tradisi (Musik Tari benten). STSI Padangpanjang.

Hutchinson, A. (1977). Labanotation or Kinetography Laban The System of Analyzing and Recording Movement. America: A Theatre Arts Books.

Indrayuda, 2013. Popularitas Tari Piring sesebagai Identitas Budaya Minangkabau. Panggung, 23 (3), 270-280.

Kaeppler, A. L. (2007). "Method and Theory in Analyzing Dance Structure with An Analysis Of Tongan Dance", dalam Dance Structures Perspective on The Analyzing of Human Movement. Budapest: Akademiai Kiado.

Lomax, A., Barternieeff, I., and Pauley, P. (1978). "Dance Style and Culture". dalam Alan Lomax. 1978. Folk Song Style and Culture. United of America: Transaction books.

Murgiyanto, S. (1991). Moving Between Unity and Diversity: Four Indonesia Choreographers. A dissertation submitted to the Faculty of the Department of
Performance Studies, Doctor of Philosphy, New York University.

Navis, A.A. (1986). Alam Terkembang Jadi Guru. Jakarta: PT Temprint.

Prakosa, R. D. (2009). Nilai Kultural Kesenian Jaranan. Panggung, 19 (4), 358-370.

Royce, A. P. (1977). The Antropology of Dance. Bloomington and London: Indiana University Press.

Rustiyanti, S. (2013). Estetika Tari Minang dalam Kesenian Randai Analisis Tekstual-Kontekstual. Panggung, 23 (1), 42-56.

Sedyawati, E. (1981). Pertumbuhan Seni Pertunjukan. Jakarta: Sinar Harapan.

----------. (1984). Tari, Tinjauan dari Berbagai Seni. Jakarta: Dunia Pustaka Jaya.

Sugiono. (2005). Memahami Penelitian Kualitatif. Bandung: CV Alfabeta.

Utama, I. (2017). Tari Minangkabau dari Pancak dan Pamenan ke Tari Persembahan. Kuala Lumpur: Universiti Malaya.

Wahyuni, W., Risnawati. (2003). Metode Pembelajaran Gaya Tari B I Gerak Dasar Tari. Dirjen Dikti Departemen Pendidikan Nasional: Sekolah Tinggi Seni Indonesia. 